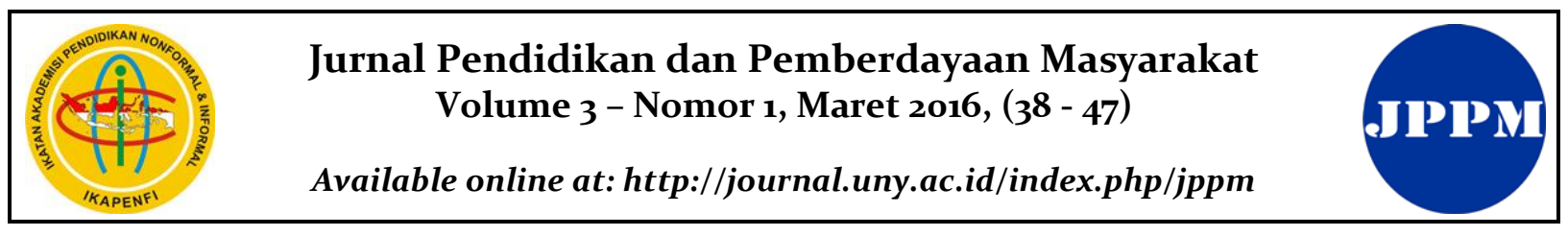

\title{
KEPEDULIAN ORANG TUA TERHADAP PENDIDIKAN ANAK UNTUK MENYELESAIKAN PROGRAM WAJAR 9 TAHUN
}

\author{
Halim K. Malik ${ }^{1)}$, Sumarno ${ }^{2)}$ \\ ${ }^{1}$ Pendidikan Luar Sekolah Universitas Negeri Gorontalo, Jl. Jenderal Sudirman No. 6 Kota \\ Gorontalo, Indonesia. Email: halimaliq@yahoo.com \\ ${ }^{2}$ Universitas Negeri Yogyakarta, Jl. Colombo No. 1, Karangmalang Yogyakarta 55281, Indonesia. \\ Email: sumarno_unj@yahoo.co.uk
}

\begin{abstract}
Abstrak
Penelitian ini bertujuan untuk mendeskripsikan tentang: (1) perhatian orang tua terhadap pentingnya pendidikan dalam hidup bermasyarakat. (2) tanggung jawab orang tua dalam menyediakan fasilitas pendidikan bagi anak. (3) orientasi nilai yang dijadikan dasar oleh orang tua dalam pendidikan anak. (4) faktor-faktor yang berpengaruh terhadap kepedulian orang tua dalam pendidikan anak untuk menyelesaikan wajib belajar 9 tahun. Penelitian ini menggunakan pendekatan kualitatif deskriptif. Teknik pengumpulan data melalui wawancara, observasi dan dokumentasi. Data yang diperoleh dianalisis dengan menggunakan analisis perbandingan tetap yaitu analisis domain, analisis taksonomi dan analisis tema, pengambilan kesimpulan dan verifikasi, sedangkan untuk mencapai kredibilitas data menggunakan ketekunan pengamatan dan triangulasi. Hasil penelitian adalah: (1) perhatian orang tua terhadap pendidikan anak sangat rendah, karena dipengaruhi oleh persepsi bahwa sekolah hanya untuk sekadar mengajarkan membaca, menulis dan berhitung. (2) orang tua tidak menyediakan fasilitas pendidikan di rumah sebagai penunjang proses belajar yang didapat di sekolah. (3) tingginya angka anak putus sekolah diakibatkan oleh nilai yang dianut oleh orang tua yang menganggap sekolah bukan jaminan untuk mendapatkan pekerjaan yang layak. (4) faktor-faktor yang berpengaruh terhadap kepedulian Orang tua adalah tidak merespon secara positif program wajib belajar 9 tahun, dan minat dan motivasi belajar anak yang justru bersumber dari lingkungan keluarga itu sendiri.
\end{abstract}

Kata Kunci: kepedulian orang tua, pendidikan wajib belajar 9 tahun

\section{PARENTS' ATTENTION TO CHILDREN EDUCATION IN COMPLETEING 9 YEAR COMPULSORY EDUCATION}

\begin{abstract}
This research is. The purpose of to describe about: (1) parental attention to the importance of education in social life. (2) the responsibility of parents to provide educational facilities for children. (3) the orientation value basis by parents in children's education. (4) factors that influence the awareness of parents in the education of children to complete nine years of compulsory education. This study employed descriptive qualitative approach. The technique of collecting data through interviews, observation and documentation. The data obtained were analyzed using comparative analysis remains the domain analysis, taxonomic analysis and theme analysis, deduction and verification, in order to achieve credibility observational data using persistence and triangulation. The results are: (1) parental supervision of children's education is very low, because it is influenced by the perception that the school is just for teaching reading, writing and arithmetic. (2) parents do not provide educational facilities at home to support learning acquired in school. (3) high rates of school dropouts due to the values embraced by parents who think school is not a guarantee to get a decent job. (4) the factors that influence parents concerns are not responding positively to 9-year compulsory education program, and the interest and motivation of children would come from the family itself.
\end{abstract}

Keywords: parental care, basic education

How to Cite: Malik, H., \& Sumarno, S. (2016). Kepedulian orang tua terhadap pendidikan anak untuk menyelesaikan program wajar 9 tahun. Jurnal Pendidikan dan Pemberdayaan Masyarakat, 3(1), 38-47. Retrieved from http://journal.uny.ac.id/index.php/jppm/article/view/8o61 


\section{PENDAHULUAN}

Dalam konteks pendidikan, sebenarnya tidak hanya sekolah sebagai representasi negara yang menjadi penanggung jawab sentral pendidikan, tetapi masih ada unsur lain, yaitu peserta didik dan masyarakat. Orang tua adalah bagian dari suatu masyarakat sehingga turut memikul tanggung jawab terhadap proses pendidikan. Kenyataannya sangat sedikit orang tua yang turut serta dalam proses pendidikan formal. Oleh karena itu, agar dalam pemahaman serta dalam bimbingan kepada anak didik tersebut tidak bertentangan dengan kodratnya, maka pendidik termasuk orang tua perlu memahami sifat-sifat anak didik maupun segala sesuatu tentang anak didik, baik anak didik di rumah, di sekolah maupun di lingkungan pergaulannya yang diwujudkan dalam bentuk kepedulian terhadap pendidikan anak.

Kepedulian adalah aspek dalam diri seseorang yang mencerminkan sikap dan tindakan yang mengandung makna adanya perhatian, dan tanggung jawab, serta nilai acuan dalam memperlakukan suatu objek tertentu (Mesarovic \& Eduardus, 1974, p.47).

Kenyataan yang ditemukan di lapangan bahwa sebagian besar anak tidak melanjutkan sekolah karena diduga orang tua sering memanfaatkan tenaga anak untuk membantu mencari nafkah di ladang dan di sawah. Ini akan membuat anak-anak mereka merasa tidak tertarik lagi untuk bersekolah. Banyak anak-anak di Kecamatan Tolangohula pada rentang usia sekolah wajib belajar 7-15 tahun menjadi pekerja, sebagian menjadi gelandangan.

Berdasarkan gambaran permasalahan yang ada, maka penelitian ini dibatasi pada "Bagaimana kepedulian orang tua terhadap pendidikan anak untuk menyelesaikan Program Wajib Belajar 9 Tahun di Kecamatan Tolangohula Kabupaten Gorontalo?".

Penelitian ini bertujuan untuk mengetahui: (1) Perhatian orang tua terhadap pentingnya pendidikan dalam hidup bermasyarakat. (2) Tanggung jawab orang tua dalam menyediakan fasilitas pendidikan bagi anak.

(3) Orientasi nilai yang dijadikan dasar oleh orang tua dalam pendidikan anak. (4) Faktor-faktor yang berpengaruh terhadap kepedulian orang tua dalam pendidikan anak untuk menyelesaikan wajib belajar 9 tahun.

Hasil penelitian ini diharapkan dapat bermanfaat: (1) Bagi para orang tua, sebagai bahan masukan betapa pentingnya pendidikan anak untuk kepentingan dirinya sendiri, keluarga, bangsa dan negara, (2) Bagi para pengambil kebijakan sebagai bahan pertimbangan dalam menyusun rancangan pembinaan terhadap orang tua tentang pentingnya pendidikan sekolah, (3) Bagi peneliti lainnya, sebagai landasan untuk penelitian berkaitan dengan kepedulian orang tua terhadap pendidikan anak.

\section{METODE}

\section{Jenis Penelitian}

Metode penelitian yang digunakan adalah metode kualitatif. Nasution, (2003, p.5) mengemukakan bahwa penelitian kualitatif pada hakekatnya adalah mengamati orang dalam lingkungan hidupnya, berinteraksi dengan mereka, berusaha memahami bahasa dan tafsiran mereka tentang dunia sekitarnya.

\section{Tempat Penelitian}

Penelitian ini dilakukan di wilayah Kecamatan Tolangohula Kabupaten Gorontalo

\section{Waktu Penelitian}

Penelitian dilaksanakan selama 8 bulan, meliputi: persiapan (pralapangan) dalam bentuk penyusunan rancangan penelitian, memilih lapangan penelitian, penyelesaian perizinan; kerja lapangan dalam bentuk pengumpulan data dan analisis data sampai dengan penyusunan laporan penelitian.

\section{Jenis Data}

Data dalam penelitian ini meliputi: (1) Perhatian orang, (2) Tanggung jawab orang tua, (3) Orientasi nilai yang dijadikan dasar oleh orang tua dalam pendidikan, dan (4) Faktor-faktor yang berpengaruh terhadap kepedulian orang tua dalam pendidikan anak untuk menyelesaikan wajar 9 tahun.

\section{Sumber Data}

Menurut Lofland \& Lofland (1948), sumber utama dalam penelitian kualitatif 


\section{Jurnal Pendidikan dan Pemberdayaan Masyarakat, 3 (1), Maret 2016 - 40}

Halim K. Malik, Sumarno

adalah kata-kata dan tindakan, selebihnya adalah data-data tambahan dan dokumen (Moleong, 200o, p.112). Yang menjadi sumber data dalam penelitian ini adalah: (1) orang tua anak putus sekolah, (2) anak-anak putus sekolah wajib belajar 9 tahun, (3) kepala-kepala sekolah dan guru-guru/instruktur dan tokoh masyarakat.

\section{Prosedur Pengumpulan dan Perekaman Data Peran Peneliti}

Kedudukan peneliti sebagai perencana, pelaksana pengumpul data, menganalis dan penafsir data, dan melaporkan hasil penelitiannya (Moleong, 2000, p.121). Keikutsertaan peneliti dalam kegiatan ini dikategorikan pada tingkat "pengamat penuh".

Tahap-tahap penelitian, yaitu tahap pra lapangan dan tahap kerja lapangan.

\section{Teknik Pengumpulan Data}

Wawancara

Wawancara dilakukan melalui teknik bola salju (snow ball).

Observasi (Pengamatan)

Dilakukan sesuai dengan pendapat Bogdan dan Biklen, bahwa selama melakukan pengamatan, peneliti membuat catatan deskriptif secara tertulis dari apa yang didengar, dilihat, dialami, dan dipikirkan dalam rangka mengumpulkan data serta memberi refleksi (Bogdan \& Biklen, 1982, p.74). Semua catatan lapangan dibuat sesuai prinsip Spradley, yang mencakup: (1) prinsip identifikasi bahasa, (2) prinsip verbalisme, (3) prinsip konkrit, (Spradley, 1990, pp.65-68).

\section{Analisis Dokumentasi}

Teknik ini digunakan selain untuk mencatat data yang terdapat dalam dokumen, juga untuk memperoleh gambaran yang lengkap tentang kondisi dokumen tersebut, termasuk di dalamnya hal-hal yang tersurat maupun tersirat. Teknik ini dikenal dengan istilah "kajian isi atau content analysis". Dokumen yang dikumpulkan oleh peneliti antara lain: jumlah orang tua yang memiliki anak putus sekolah, tingkat pendi- dikan orang tua, dan tingkat pendapatan orang tua.

Proses Pencatatan (Perekaman Data)

Proses pencatatan, yaitu: (1) pencatatan data dilakukan dalam format catatan lapangan; (2) membuat coding, (3) memilih alat yang mudah digunakan dalam pengumpulan data.

\section{Analisis dan Penafsiran Data}

Teknik analisis dan penafsiran data adalah analisis perbandingan tetap, sebagaimana dikemukakan oleh Spradley, yaitu: (1) analisis domain, (2) analisis taksonomi, dan (3) analisis tema (Spradley, 1990, p.116).

Langkah-langkah penafsiran data perbandingan tetap; (1) Mulai dengan pengumpulan data. (2) Mencari isu penting, kejadian yang selalu berulang atau kegiatan di dalam data yang merupakan kategori fokus. (3) Mengumpulkan data yang memberikan banyak kejadian mengenai kategori fokus untuk melihat adanya keragaman dimensi di dalam kategori. (4) Tulis kategori-kategori yang sedang diselidiki, dengan maksud untuk memberikan dan menjelaskan semua keadaan yang ada pada data anda sementara terus mencari kejadian-kejadian yang baru. (5) Kerjakan data yang diperoleh dan model yang muncul untuk menemukan adanya proses-proses sosial dasar dan hubunganhubungan (Munandir, 1989, p.149).

\section{Pemeriksaan Keabsahan Data}

Untuk kepentingan penelitian ini, digunakan teknik pemeriksaan keabsahan data, yakni antara lain: (1) ketekunan pengamatan, dan (2) triangulasi.

\section{Verifikasi dan Penarikan Kesimpulan}

Dalam melakukan dan menarik kesimpulan dalam penelitian ini akan dilakukan dengan cara meninjau kembali sajian data serta catatan lapangan mengenai perhatian orang tua, tanggung jawab orang tua, orientasi nilai yang dijadikan orang tua dalam pendidikan anaknya, serta faktor-faktor yang berpengaruh terhadap kepedulian orang tua dalam pendidikan anak untuk menyelesaikan program wajib belajar sembilan tahun. 
Jurnal Pendidikan dan Pemberdayaan Masyarakat, 3 (1), Maret 2016 - 41

Halim K. Malik, Sumarno

\section{HASIL DAN PEMBAHASAN}

Tabel 1. Jumlah Penduduk Menurut Pendidikan Tertinggi

yang Ditamatkan Menurut Desa di Kecamatan Tolangohula

\begin{tabular}{ccccccccc}
\hline Nama Desa & $\begin{array}{c}\text { Belum Pernah Sekolah/ } \\
\text { Tidak Tamat SD }\end{array}$ & SD & SLTP & SLTA & D-1/D-2 & D-3 & S-1 & Jumlah \\
\hline Gandasari & 1525 & 81 & 101 & 572 & - & 2 & 14 & 2295 \\
Sukamakmur & 1593 & 450 & 102 & 75 & 13 & 18 & 2261 \\
Molohu & - & - & - & - & 8 & - & - & - \\
Lakeya & 656 & 135 & 68 & 112 & 10 & 10 & 991 \\
Binajaya & 689 & 945 & 88 & 24 & - & 5 & 1751 \\
Polohungo & 828 & 123 & 54 & 41 & - & - & 1046 \\
Tamaila Utara & 637 & 298 & 58 & 28 & 1 & 1 & 1 & 1023 \\
Sidoharjo & 525 & 581 & 265 & 190 & 3 & & 4 & 1568 \\
Sukamakmur Utara & 269 & 831 & 81 & 59 & 3 & 2 & 1245 \\
Margomulya & 389 & 281 & 77 & 76 & 1 & & - & 824 \\
Makmur Abadi & 1194 & 137 & 84 & 100 & - & 1 & 3 & 1519 \\
Gandaria & 1860 & 57 & 66 & 97 & 9 & - & 2089 \\
Ombulo Tango & - & - & - & - & - & - & - & - \\
Tamaila & 1134 & 581 & 236 & 175 & 3 & - & 4 & 2123 \\
Himalaya & - & - & - & - & - & - & - & - \\
Jumlah & - & - & - & - & - & - & - & - \\
\hline
\end{tabular}

Sumber: Tolangohula dalam angka 2009/2010

Data anak usia wajib belajar yang putus sekolah atau dropout yang teridentifikasi di sejumlah desa di Kecamatan Tolangohula tahun 2007-2008 adalah sebagai berikut: usia 7-12 tahun sebanyak 239 (dua ratus tiga puluh sembilan) orang, usia 13-15 tahun sebanyak 355 (tiga ratus lima puluh lima) orang. Jumlah anak usia wajib belajar yang terlayani di sekolah formal dan kelompok belajar Paket A dan B sebanyak 215 orang dan jumlah anak yang belum mendapatkan pelayanan pendidikan 379 orang.

Dengan melihat kondisi tersebut dapat dipahami bahwa tingkat pendidikan di Kecamatan Tolangohula sangat rendah, karena masih banyak anak usia wajib belajar sembilan tahun yang tidak melanjutkan ke sekolah formal atau nonformal. Rendahnya anak putus sekolah di Kecamatan Tolangohula dipengaruhi oleh faktor motivasi internal dan faktor eksternal (orang tua dan lingkungan).

Sebagian besar penduduk tidak sekolah atau tidak tamat SD yang diakibatkan putus sekolah dengan berbagai macam penyebab. Untuk lebih jelasnya data tentang jumlah penduduk menurut pendidikan yang ditamatkan di seluruh kecamatan yang ada di Kecamatan Tolangohula dapat dilihat pada Tabel 1.
Tabel 1 menunjukkan bahwa penduduk Kecamatan Tolangohula masih banyak yang belum pernah sekolah atau tidak tamat SD sejumlah 11.299 orang, dan penduduk yang lulus/tamat SD dan SLTP sejumlah 5780 orang. Data penduduk yang belum/ tidak tamat SD ini masih terhitung sedikit karena masih ada 4 desa yang datanya belum masuk ke Kecamatan Tolangohula.

\section{Tradisi Peladang Berpindah}

Kearifan lokal daerah Gorontalo dikenal dengan istilah "dulo ito memongu lipu" (mari kita membangun negeri). "Dulo ito memongu lipu" itu sendiri mengandung makna ajakan kepada semua lapisan masyarakat agar turut serta dalam pembangunan. Dalam pembangunan suatu daerah, yang menjadi faktor penentu adalah manusianya, karena sebagai pelaksana dan sekaligus sebagai sasaran pembangunan itu sendiri.

Berdasarkan wawancara dengan Kepala Desa Bina Jaya (Bapak Iwan, 12 Juli 2008) Masyarakat di Tolangohula khususnya di Desa Bina Jaya masih cenderung menganut banyak tradisi (budaya), antara lain: tradisi peladang berpindah, tradisi huyula (berkumpul/bersatu) dan heluma (gotong royong). Tradisi ini dilaksanakan secara turun-temurun oleh sebagian masyarakat 


\section{Jurnal Pendidikan dan Pemberdayaan Masyarakat, 3 (1), Maret 2016 - 42}

Halim K. Malik, Sumarno

Tolangohula. Untuk tradisi peladang berpindah, tidak hanya orang tua atau kepala keluarga yang bermigrasi/berpindah mencari lahan lain untuk bercocok tanam, tetapi seluruh keluarga termasuk anak yang masih duduk di bangku sekolah. Akibat dari tradisi ladang berpindah ini, maka banyak anak yang terpaksa putus sekolah.

Tingginya angka putus sekolah wajib belajar 9 tahun yang ada di Kecamatan Tolangohula tidak hanya diakibatkan oleh kebiasaan mengikuti orang tua untuk berladang berpindah. Penyebab lainnya adalah saat musim tanam yang membutuhkan waktu sampai dua atau tiga hari. Selama masa tanam, anak juga ikut orang tuanya ke ladang, sehingga menggangu waktu sekolahnya. Biasanya sepulang dari ladang masih sangat lelah karena menempuh perjalanan 5 sampai 6 jam atau lebih. Keadaan fisik yang masih lelah sangat berpengaruh terhadap minat dan motivasi. Akibatnya waktu waktu belajar anak di sekolah terganggu dan tidak efektif.

Hal ini tidak sejalan dengan apa yang diungkapkan oleh Whitengton (1978), bahwa pada dasarnya pendidikan adalah suatu proses yang sengaja dilakukan untuk mengembangkan kepribadian dan kemampuan seseorang.

\section{Nikah Muda (Bawah Umur)}

Di Kecamatan Tolangohula Kabupaten Gorontalo, kawin di usia muda dianggap sebagai tradisi yang lumrah, Di samping karena lemahnya penegakan hukum perkawinan dan faktor sosio-ekonomi dan geografis. Tidak sedikit dari anak-anak yang masih dalam usia sekolah telah menjalani pernikahan di usia muda. Anak-anak yang seharusnya masih dalam tanggung jawab orang tua telah melepas masa lajang.

Umumnya orang tua, terkesan ingin melepas rasa tanggung jawabnya dan menyerahkan tanggung jawab kepada suami. Hal ini terungkap dari hasil wawancara dengan (Taci Ine)

"Kalau sudah kawin, sudah tidak ada beban lagi. Tidak khawatir dan cemas dan tanggungan hidup juga berkurang. Anak saya dua-duanya (Nur dan Yana) begitu ada yang minta langsung saya terima supaya tidak ada lagi yang bikin pusing daripada tiap malam saya selalu khawatif kalau anak-anak belum pulang". (wawancara, 18 Februari 2009)

Penyebab kasus-kasus kawin muda yang ada di Kecamatan Tolangohula memang belum terungkap secara detail. Namun dapat katakan bahwa kawin muda di Kecamatan Tolangohula dianggap wajar oleh sebagian masyarakat, terutama orang tua yang tingkat pendidikannya rendah. Sebagian orang tua ingin melepas tanggung jawabnya, sebagian karena keterpaksaan karena hamil di luar nikah, dan sebagian lagi karena tergiur oleh latar belakang ekonomi keluarga yang melamar anaknya.

\section{Anak Jadi Tenaga Kerja}

Anak-anak yang seharusnya mendapat hak untuk mendapatkan pendidikan yang layak telah terbius dengan upah yang sebenarnya "rendah", tetapi sebagian anakanak telah terbawa arus dan lambat laun lupa akan kewajibannya untuk bersekolah. Yang lebih memprihatinkan lagi, biasanya anak-anak diajak oleh dengan orang tua untuk bekerja, misalnya di sawah, di ladang, dan berbagai pekerjaan lainnya yang dianggap mampu dilakukan oleh anak-anaknya. Akhirnya anak-anak yang seharusnya masih membutuhkan pendidikan menjadi tenaga kerja atau buruh di beberapa tempat, (sawah, ladang, pabrik gula, gilingan padi,dan gilingan jagung, pasar dan lain sebagianya).

Menjadi tenaga kerja awalnya bukan menjadi pilihan, akan tetapi oleh sebagian orang tua telah dimanfaatkan dan dieksploitasi untuk membantu kebutuhan ekonomi keluarga. Hal ini terungkap dari penuturan Muhammad Madina (47 tahun, guru di salah satu sekolah di Kecamatan Tolangohula) bahwa "kalau anak-anak sudah mulai jarang sekolah, maka setelah kita telusuri ternyata mereka menjadi buruh "menjemur hasil panen" jagung, padi, di gilingan-gilingan atau pekerjaan lain yang sifatnya musiman, sebagian ikut orang tua mencari rotan, menjadi tukang tebang tebu dan lain sebagainya. Hal ini menjadi penyebab anak 


\section{Jurnal Pendidikan dan Pemberdayaan Masyarakat, 3 (1), Maret 2016 - 43}

Halim K. Malik, Sumarno

tidak naik kelas, malas, dan akhirnya berhenti bersekolah".

\section{Perhatian Orang Tua}

Hasil wawancara dengan Ibu Ine (13/o8/2008) adalah sebagai berikut:

"Saya mengharapkan anak saya menjadi anak yang mampu membaca, menulis dan berhitung sebagai bekalnya di masa depan. Tidak perlu sekolah yang tinggitinggi, yang penting sudah bisa membaca dan menulis saja itu sudah cukup. Lagi pula anak saya sudah pintar mencari uang sendiri. Kalau musim panen jagung tiba, anak saya biasa bekerja di bagian pengeringan, dan uang yang didapatnya digunakan untuk membeli keperluannya. Sekarang banyak lapangan pekerjaan di desa yang bisa menjadi sumber mata pencaharian. Menjadi ojek motor, menjadi penggarap sawah, menjadi buruh tebang tebu, atau bisa sama-sama dengan kami menggarap lahan sendiri atau lahan orang lain."

Pernyataan Ibu Ine senada dengan apa yang diungkapkan oleh Siko dan Asrin, mengemukakan bahwa

"Anak kami putus sekolah kelas IV SD. Tiba-tiba saja dia sudah tidak mau sekolah, tidak ada alasan mengapa dia sampai tidak mau lagi bersekolah. Menurut pengakuan gurunya, dia tidak bodoh di sekolah dan termasuk anak yang penurut. Sudah berulang kali gurunya membujuk untuk bersekolah lagi tapi anak saya sudah tetap tidak mau. Mau apa lagi? Padahal kami menginginkan agar dia tidak putus sekolah. Apalagi sekolah dekat dengan rumah. Ya, kami pasrah saja. Mungkin karena pengaruh sepulang sekolah tidak ada orang di rumah, sebab kami setiap hari harus bekerja di kebun. Sekarang dia sering ikut kami ke kebun. Kakaknya yang perempuan Alhamdulillah Tamat SD, kami titipkan di neneknya yang tidak jauh dari lahan yang kami garap. Dia lebih senang dengan neneknya. Dia sebetulnya ingin sekolah di SMP tapi maunya SMP di Kabupaten. Kami tidak mengizinkan karena khawatir dia perempuan, akhirnya dia memilih untuk tidak bersekolah. Apalagi biaya sekolah di Kabupaten lumayan mahal, per-lengkapan sekolah seperti sepatu dan tas bersaing merek.

Sangat disayangkan jika penyebab tingginya angka anak putus sekolah hanya karena kurangnya perhatian dari orang tua anak mereka. Dari pihak sekolah sudah berusaha untuk mengadakan home visit (guru kunjung) ke rumah masing-masing anak yang sering bolos sekolah. Sebagaimana dituturkan oleh Sukri Utiarahman salah seorang guru wali kelas IV SDN suka makmur Kecamatan Tolangohula,

"Sering kami melakukan kunjungan ke rumah-rumah, tetapi apa yang kami dapatkan adalah sia-sia. Pendidikan memang tanggung jawab kita bersama, guru, orang tua dan masyarakat dan siswa itu sendiri. Saya rasa faktor penyebab utama dari anak putus sekolah sangat kecil dari pihak si anak. Kalau anak-anak itu kita arahkan dan bimbing dengan penuh sabar dan penuh perhatian, mereka akan menjadi anak yang baik, penurut dan bermoral. Umumnya mereka yang sering bolos karena kurang perhatian dari orang tua, bahkan orang tua seolah-olah mengangap bahwa pendidikan itu tidak begitu penting.

Yang dikunjungi tidak berada di tempat, dan saya hanya mendapat laporan dari tetangga bahwa seluruh keluarga pergi karena ada hajatan di salah satu keluarganya di kecamatan lain. Hal seperti ini sudah sering terjadi dan kamipun selalu berusaha menyadarkan orang tua mereka. Kami tidak punya waktu terus-menerus mengontrol perilaku anak-anak di rumah, karena kami pun ada keluarga sendiri yang harus kami urus, apalagi tugas dan tanggung jawab saya sebagai wali kelas itu berat. Sudah capek dan sudah cukup mengingatkan orang tua. Jalan satu-satunya yang ditempuh adalah anak yang bersang-kutan tidak lulus atau tidak naik kelas. Akhirnya sekolah kami hampir setiap tahun angka kelulusannya di 


\section{Jurnal Pendidikan dan Pemberdayaan Masyarakat, 3 (1), Maret 2016 - 44 \\ Halim K. Malik, Sumarno}

bawah 100\%. (wawancara, 25 Oktober 2008)

Persepsi atau pemahaman yang kurang dari orang tua anak putus sekolah terhadap konsep pendidikan di Kecamatan Tolangohula merupakan penyebab kurangnya perhatian atau partisipasi sehingga orang tua seolah-olah acuh tak acuh dan tidak mau terlibat dalam proses pendidikan. Hal ini seiring dan sejalan dengan definisi perhatian menurut Worell \& Stilwell (1981, p.92), bahwa perhatian sebagai suatu strategi kognitif yang mencakup empat aspek, yaitu: (1) berorientasi kepada masalah, (2) meninjau sepintas isi masalah, (3) memusatkan diri pada aspek-aspek yang relevan, dan (4) mengabaikan stimuli yang tidak relevan. Teori lain yang menjelaskan faktor terbentuknya perhatian adalah teori model kesesuaian (congruence model theori) yang dikembangkan oleh Boshier. (Gibson \& Graff, 1992, p.2).

\section{Tanggung Jawab Orang}

Perhatian dan tanggung jawab sebagai amanat Allah untuk mendidik anak keturunannya telah diabaikan oleh sebagian orang tua. Sebagaimana yang terungkap dari penuturan ibu Diana Ngau:

"Hampir semua permasalahan anak-anak putus sekolah dan yang terancam putus sekolah sudah sering kami hadapi. Umumnya anak putus sekolah adalah anak-anak yang orang tuanya bermasalah antara lain masalah ekonomi, broken home, orang tua yang kurang peduli, dan lain-lain. Tapi yang paling menonjol adalah masalah orang tua yang kurang perduli dan kurang bertanggung jawab pada pendidikan anaknya. (wawancara 22 September 2008)

Pernyataan Ibu Diana, ditegaskan oleh Bapak Muhammad Madina:

Mengajar di sini (Tolangohula) tidak sama dengan di kota, anak-anak di sini terlantar dan ditelantarkan oleh orang tua, jangan dulu bicara tanggung jawab, perhatian saja kurang. Banyak anak-anak yang datang sekolah awut-awutan atau tidak rapi. Itu artinya orang tua tidak ada perhatian. Kalau untuk perhatian saja kurang apalagi tanggung jawab. Ada yang tidak memakai sampai-sampai tidak membawa pensil/pena ke sekolah, ada yang buku tulisnya sudah penuh, dan tinggal menulis di sampul buku. Kalau anak-anak di kota perhatian dan tanggung jawab itu malah berlebihan, tapi di sini anak dibiarkan berkembang sendiri dan menemukan jalannya sendiri. Sifat orang tua itu tercermin dari anak-anak itu. (wawancara, Juli 2009)

Ketimpangan antara cita-cita anak dengan kenyataan yang terjadi pada sebagian orang tua siswa putus sekolah menjadi penyebab munculnya anak putus sekolah. Menurut Crano (1982, p.326) batasan tentang tanggung jawab adalah sebagai keadaan seseorang yang dalam melakukan tindakan sesuai yang diperlukan. Tanggung jawab meliputi perasaan dan kewajiban untuk melakukan apa yang seharusnya dilakukan dengan benar.

\section{Orientasi Nilai}

Orientasi Nilai Egoistik (mosikola ja tunggulo ode utonu)

Di mata orang tua tidak dikenal "Anak idaman" sebagaimana hasil wawancara dengan Danial Duengo:

"Sikola ja tunggulo de utonu, (setinggi apapun sekolah tidak ada gunanya) Sekolah tidak menjamin anak saya menjadi pegawai negeri. Saya sengaja menyuruh anak berhenti sekolah karena kenyataan sekarang banyak yang sekolahnya tinggitinggi akhirnya kembali ke kampung dan statusnya sama dengan orang-orang yang tidak pernah sekolah. Uang orang tua sudah habis hanya untuk biaya sekolahnya. Hasilnya hanya selembar kertas yang hanya membuktikan bahwa kita pernah sekolah. Mau bekerja di sawah dan di ladang tidak punya pengalaman, kelebihannya hanya pintar berbicara. Saya bandingkan dengan anak saya yang tidak tamat SMP tapi bisa bekerja di sawah dan diladang. Tapi anak saya tidak merugikan saya harus menjual apa-apa,bahkan sudah 


\section{Jurnal Pendidikan dan Pemberdayaan Masyarakat, 3 (1), Maret 2016 - 45}

Halim K. Malik, Sumarno

bisa membantu meringankan pekerjaan saya. (wawancara, 4 Juli 2009)

Setiap orang tua memiliki yang dominan yang menjadi orientasi nilai yang dianggapnya benar dalam suatu masyarakat. Namun kondisi yang ditemukan di Kecamatan Tolangohula termasuk unik, yaitu berorientasi ke masa lalu. Dimensi waktu lampau yang telah terlewati telah beruratakar sehingga sangat berpengaruh dalam keyakinannya dalam mengambil suatu keputusan. Keputusan yang diambil justru bertentangan dengan kodratnya sebagai orang tua yang harus ber-tanggung jawab terhadap pendidikan anak-anaknya. Akibatnya kehidupan mereka terbelakang dan sangat jauh dari perkembangan dan kemajuan zaman. Sementara di sisi lain pemerintah selalu memberikan kemudahan agar masyarakatnya bisa berubah menjadi masyarakat yang hidup layak dan berpen-didikan.

\section{Orientasi Nilai Materi}

Masyarakat Tolangohula cenderung mengejar materi' untuk bekal di hari tua dan untuk warisan anak cucu mereka. Hal ini ter-ungkap saat wawancara dengan salah seorang orang tokoh masyarakat (Muh. Puluhulawa) bahwa:

"Setiap ada kesempatan mereka gunakan untuk mencari pekerjaan yang bisa menghasilkan uang bahkan sampai dengan merambah hutan. Hutan yang dibuka akan dijadikan ladang atau sawah. Pada saat-saat seperti ini biasanya seluruh keluarga akan bermigrasi dan akan mendirikan "sabuwa" (pondok kecil) sebagai rumah sementara. (wawancara 15 Oktober 2008).

Apa yang dituturkan di atas, menunjukkan bahwa sebagian masyarakat dalam hal ini orang tua yang memiliki berorientasi pada materi (uang) tanpa memikirkan masa depan dan cita-cita anak-anaknya. Pekerjaan sampingan untuk mendapatkan upah menjadi pilihan jika gagal panen, sebagaimana yang dituturkan oleh Marten Madina (47 tahun, Tokoh masyarakat)

"Jika gagal panen masih ada pekerjaan alternatif, "makan gaji" (menjadi buruh) di tempat lain, misalnya menjadi penebang tebu, dan menjadi "tukang tarik" kayu gelondongan di hutan dengan modal sepasang sapi, atau mencari rotan untuk dijual ke penadah, atau "makan gaji" menjemur jagung atau padi di gilingan-gilingan padi. Tapi pekerjaan itu musiman sifatnya, misalnya untuk menjadi buruh pabrik gula (menjadi penebang tebu) hanya setahun sekali, karena pabrik kapasitasnya terlalu besar sementara lahan tebu tidak mencukupi memenuhi permintaan pabrik. Orang tua dan anakanak putus sekolah menjadi buruh di sana, atau mencari pekerjaan-pekerjaan lain yang bisa menghasilkan uang, sebagian menjadi tukang ojek, menyiangi tanaman dan mencabut rumput di sawah dan pekerjaan serabutan lainnya. (wawancara, 18 September 2009).

Mencermati orientasi nilai-nilai yang masyarakat Kecamatan Tolangohula dalam hal ini orang tua anak putus sekolah sebagaimana dituturkan di atas, jelaslah bahwa sebagian masyarakat Tolangohula terlalu menggantungkan nasibnya pada alam yang semakin hari semakin terkuras, dan untuk mempertahankan hidupnya pada masa-masa sulit, mereka akan mencari pekerjaan alternatif.

\section{Orientasi Nilai "ngolimbunga"}

Salah satu pepatah yang terkenal di beberapa lingkungan masyarakat "openu de hepoalo'u asali jamoheyi totiliu" (Biarlah aku yang menanggung kehidupannya asalkan tidak pergi jauh). Prinsip "openu de hepoalo'u asali jamoheyi totiliu” pada akhirnya nilainilai kebersamaan itu pada akhirnya memupus secara perlahan-lahan dan menafikan kebutuhan-kebutuhan lain termasuk hak untuk mendapatkan pendidikan pendidikan yang layak. Sikap orang tua yang terus mempertahankan kebersamaan bersama anggota keluarga, ternyata mampu menghadirkan suasana yang nyaman, tenteram dan tulus. Sebagian orang (anak) mampu melapaskan diri dalam kukungkungan dan keterasingan dari dunia luar. Hal ini terungkap saat wawancara dengan Tune (51 Tahun) 


\section{Jurnal Pendidikan dan Pemberdayaan Masyarakat, 3 (1), Maret 2016 - 46}

Halim K. Malik, Sumarno

“openu dehepoalo latiya takeke'ina tiye asali jamoheyi to talu latiya. Donggo wolo uhesikolalo, bo mobaca uparalu. Dadata ukarajalo wanu to kambungu, bo moposadiya batanga. Timola tayilo tisikosikola molanggato debo jaokaraja” Tingga halalelo hipakuwa mola tokambungu dadata umali karajalo. Wanu bomokaraja timota woluwo ilengi wolo sapi hisadiyawa" (biarlah anak-anak ini saya yang menanggung makannya, asal tidak kemana-mana. Sekolah untuk apa lagi? Yang penting sudah bisa baca. Banyak yang sekolah tinggi-tinggi belum dapat pekerjaan. Lebih baik menetap di kampung banyak yang bisa dikerjakan. Kalau hanya ingin bekerja ada kebun dan sapi tersedia. (wawancara, 11 Desember 2010)

Dari aktivitas kehidupan sehari-hari kelompok masyarakat ini mementingkan hubungan kekeluargaan dalam segala aspek kehidupan saling berbagi dan saling mencukupi satu sama lain. Untuk mendapatkan gambaran aktivitas kekeluargaan dapat disimak dari penuturan Ka'Pena (59 tahun) sebagai berikut:

"Tumula teya, odelo tumu-tumulo to limbunga lo tamohutato, wonu luwasi ta ngota, olamita lo tihedu, odito olo wonu batanga lo hihilaho woluwo umotapu. Humayamali, utongango luwalolo, mongilaboto wutata puluwa" (Kami di sini sudah seperti satu keluarga, senasib sepenanggungan, jika salah satu dari kami lagi memiliki kelebihan, maka semua tetangga dapat meninkmati, demikian sebaliknya, ibaratnya melebihi saudara kandung. (wawancara, 15 Januari 2009)

Nilai kebersamaan dan kekerabatan yang dianut telah berdampak pada hak anak untuk mendapatkan pendidikan yang layak.

\section{Faktor-faktor yang Berpengaruh terhadap Kepedulian Orang Tua}

Apresiasi dan Tingkat Penerimaan Informasi

Sebagaimana diungkapkan oleh Ibu Suryani Hatibie (wawancara, 19 September 2009)

"Informasi tentang wajib belajar sudah sampai ke seluruh lapisan masyarakat, bahkan ke lokasi-lokasi yang sulit dijangkau. Jawabannya orang tua sangat meyakinkan "oh, bagus itu" tapi kenyatannya setelah ditunggu-tunggu tidak ada yang mau ikut program pendidikan setara SD dan setara SMP. Dan setelah kami telusuri, ternyata anak-anak tersebut masih membantu orang tuanya atau masih menyelesaikan pekerjaan borongan di tempat lain.

Apresiasi orang tua sangat kurang terhadap program wajib belajar 9 tahun tersangkut paut dengan kepekaan rasa yang dimilikinya, terhadap masa depan anakanaknya akan kebutuhan pendidikan. Salah satu aspek penting dari sikap adalah dimensi rasa, yaitu hal-hal yang berhubungan dengan perasaan seseorang dan dilihat dari rasa suka atau tidak suka, senang atau tidak senang. Sikap menurut Edwards (1975, p.2) adalah: "tingkatan perasaan positif dan negatif yang dikaitkan dengan suatu objek sikap”. Hal ini dipertegas oleh Azwar (2002, p.5), bahwa: "sikap adalah derajat afek positif atau afek negatif terhadap suatu objek". Selanjutnya Azwar (2002, p.70), mengemukakan bahwa sikap juga mengandung unsur evaluatif terhadap suatu objek sikap. Dipertegas oleh Sarwono (2002, p.232), bahwa: "ciri-ciri sikap mempunyai objek tertentu dan mengandung unsur penilaian".

\section{Minat dan Motivasi Belajar Anak}

Di Kecamatan Tolangohula, faktor ekonomi tidak bisa dijadikan alasan penyebab anak putus sekolah, karena sekarang ini semua sekolah formal menawarkan sekolah gratis, sebagaimana diungkapkan oleh: Pak Muhammad Puluhulawa "di setiap desa di Kecamatan Tolangohula anak putus sekolah mulai ber-kurang. Anak-anak yang terancam putus sekolah karena masalah jarak sudah disediakan sepeda gratis dari dana PNPM. (wawancara, 28 November 2010)

Pernyataan tersebut dipertegas oleh Ibu Rosmawaty

"Jarak rumah dan sekolah sudah bukan masalah lagi bagi anak-anak yang telah putus sekolah dan yang terancam putus sekolah. Anak-anak yang sempat putus sekolah dengan alasan jarak antara 


\section{Jurnal Pendidikan dan Pemberdayaan Masyarakat, 3 (1), Maret 2016 - 47 \\ Halim K. Malik, Sumarno}

sekolah dan rumah sangat jauh sampai 34 kilometer pemerintah sudah menyediakan sepeda dari dana PNPM. Tetapi yang belum mendapat layanan pendidik-an masih sekitar 25\%. (wawancara, 29 Maret 2010)

Hal-hal yang mendasari minat seseorang menurut Crow \& Crow, (1979, p.153) dapat digolongkan menjadi tiga faktor, yaitu: (1) faktor dorongan dari dalam, (2) faktor motif sosial, (3) faktor emosional.

\section{SIMPULAN}

Hampir tidak ada orang tua anak putus sekolah yang memberikan perhatian dan memberikan pemahaman terhadap anak-anaknya tentang pentingnya pendidikan sebagai bekal di masa depannya. Orang tua tidak pernah berharap apalagi bermimpi anaknya memiliki masa depan yang lebih baik dari mereka, minimal lebih baik dari pendidikan yang pernah mereka alami.

Penyebab anak putus sekolah di Kecamatan Tolangohula adalah ketidakpedulian mereka dalam memenuhi tanggung jawab dalam pemenuhan fasilitas pendidikan.

Gagalnya anak dalam sekolah lebih dipengaruhi oleh orientasi nilai yang dianut oleh orang tua, dan hanya sebagian kecil dari faktor minat dan motivasi anak.

\section{DAFTAR PUSTAKA}

Azwar, S. (2002). Sikap manusia teori dan pengukurannya edisi ke 2. Yogyakarta: Pustaka Pelajar

Bogdan, R.C. \& Biklen, S.K (1982). Qualitative research for education: An introduction to theory and methods. Boston: Allyn and BCON Inc.

Bogdan, R.C. \& Taylor S.J. (1975). Introduction to qualitative research methods: a phenomenological approach to the social sciences. Hoboken, New Jersey: John Wiley \& Sons.Inc.

Crano, W.D. (1982). Social psychology: Principle and theme of interpersonal behavior. Home World: Dorsley Press.
Crow, L.D \& Crow, AVB. (1979). Educational psychology. New York: American Book Co.

Edwards, Allen L. (1975). Techniques of attitude scale construction. New York: Appleton-Century Crofts.

Gibson, C.C \& Graff, A.O. (1992).Impact of adults' preferred learning styles and perception of barriers on completion of external baccalaureate degree programs. The International Journal of E-Learning \& Distance Education,7 (1), 39-51. Retrieved from http://ijede.ca/index.php/jde/article/vi $\mathrm{ew} / 413$

Mesarovic, M \& Eduards, P. (1974). Mankind at the turning point. New York: EP. Dutton and Co. Inc.

Moleong, L.J. (2000). Metodologi penelitian kualitatif. Bandung: Remaja Rosdakarya.

Munandir. (1989). Metodologi penelitian kualitatif. Yogyakarta: Rake Sarasin.

Robbins, S.P. (1996). Organizational behavior: concepts, controversies, applications. New Jersey: Englewood Cliffs.

Sarwono, S.W. (2002). Psikologi sosial individu dan teori-teori psikologi sosial. Balai Pustaka, Jakarta

Segall, M.H., Dasen, P.R., Berry, J.W., Poortinga, J.W. (1999). Human behavior in global perspective: an introduction to cross-cultural psychology. Boston: Pearson-Allyn and Bacon.

Smith, A.N \& D.B Medley. (1987). Information resource management. Cincinnati Ohio: South-Western Publishing Co.

Spradley, J.P. (1990). Participant observation. New York: Holt, Rinehart and Winston.

Stern, T.D. \& Kalof, L. (1998). Value orientationes, gender and environmental concern. Toronto: Elly Inc.

Worell, J \& Stilwell, W.E. (1981). Psychology for teachers and students. New York: McGraw-Hill 